\title{
Influence Organizational Citizenship Behavior and Work Motivation on Job Performance of PT JNE Kota Kediri
}

\author{
Ria Lestari Pangastuti, Desi Kristanti \\ Faculty of Economics, University of Kadiri \\ Kediri, East Java, Indonesia \\ ria_lestari@unik-kediri.ac.id ; desikristanti@unik-kediri.ac.id
}

\begin{tabular}{|lr|}
\hline & Published: 02/03/2021 \\
\hline How to cite (in APA style): \\
Pangastuti, R.L., \& Kristanti, D. (2021). Influence Organizational Citizenship Behavior and Work \\
Motivation on Job Performance of PT JNE Kota Kediri. Jurnal Ekonomi dan Bisnis Jagaditha, 8 \\
(1), 48-60. Doi: https://doi.org/10.22225/jj.8.1.2786.48-60 \\
\hline
\end{tabular}

\begin{abstract}
Organizations are systems and human activities that work together. In line with that, the organization is said to be a rational coordination of the activities of a number of people to achieve some general goals through the division of work and functions through a hierarchy of authority and responsibility. Analyzing the influence of motivation on job performance, analyzing the effect of job satisfaction on job performance, analyzing the influence of motivation on job satisfaction. This type of research is correlational analytic research. Correlation analysis is a statistical method used to measure the magnitude of the linear relationship between two or more variables. SEM, a complete modeling, basically consists of a measurement model (Measurement Model) and a Structural Model or Causal Model. This research is empirical evidence regarding the effect of motivation and OCB on achievement. This study uses a sample of 100 respondents who are employees of PT JNE Kota Kediri. The results showed that: motivation has an effect on OCB where effective motivation can increase or encourage an employee to feel satisfied, motivation has an effect on achievement. Where an employee who is committed to the organization will feel happy to be part of the organization, have trust and good feelings for the organization and have a desire to remain in the organization, and intend to do what is best for the organization.
\end{abstract}

Keywords: Organizational Citizenship Behavior (OCB), Motivation, Job Performance.

\section{INTRODUCTION}

Organizations are systems and human activities that work together (Pouramini \& Fayyazi, 2015). In line with that, the organization is said to be a rational coordination of the activities of a number of people to achieve some general goals through the division of work and functions through a hierarchy of authority and responsibility (Ghanbari \& Eskandari, 2013). This illustrates that the organization has certain characteristics that are structured and its goals are interconnected and depend on human communication to coordinate activities in the organization (Dharma, 2018). It can be said that the organization has a goal of being able to meet the needs of life so that it can get satisfaction (Newman, Nielsen, \& Miao, 2015). Therefore, the organization expects employees to excel and be able to create conducive situations and conditions so that employees will not experience burnout, boredom, and laziness to work which results in decreased morale (Afsar \& Badir, 2016). This is because if morale decreases it can result in a decrease in employee performance (Bolino, Hsiung, Harvey, \& LePine, 2015). Decreased employee performance will result in losses to the organization (Lam, Liang, Ashford, \& Lee, 2015).

Work can be completed more quickly and precisely without reducing the existing discipline if supported by the participation of a leader (Matta, Scott, Koopman, \& Conlon, 2015). In this case the leader must always provide direction, foster, and motivate subordinates in completing work to achieve organizational goals (Margahana, Haryono, \& Muftasa, 2018). This is always done by the leadership by providing 
motivation and a balance of wages for the work of employees (Brockner et al., 2006).

Organizational Citizenship Behavior

(OCB) is a set of behaviors in a free work environment that exceeds the basic job requirements of an employee, but it is considered vital for the survival of an organization, it states that OCB organizational behavior is positively related to individual performance, team work and organizational performance, therefore it is not sufficient for employees in the company. to just run each task without having any extra behavior (Basu, Pradhan, \& Tewari, 2017).

Employee motivation to engage in OCB is determined by how much the employee wants to engage in the behavior and some employees feel that he or she should engage in some behavior (Devece, Palacios-Marqués, \& Pilar Alguacil, 2015). The phenomenon in the field shows that low OCB is influenced by several factors, including: the cultural context and leadership behavior at a change of leadership which makes a JNE courier feel the need for adjustments to a change of leadership which indirectly changes the habits of employees at JNE who have been quite relaxed to be very disciplined. this is felt by courier employees. Gap research but better cooperation between colleagues is still needed to increase cohesiveness and morale. Employee motivation is good, but it needs to be improved in terms of awareness, career development, and employee welfare (Dharma, 2018).

Motivation needs to be carried out in an organization, where all activities and tasks are based on high motivation, the work performance will also be high and vice versa $(\mathrm{Ng}, \mathrm{Lam}, \&$ Feldman, 2016). In order for someone to want to do a job, that person needs motivation (Koning \& Van Kleef, 2015). Motivation is something or something that encourages someone to do something (Zhang, Guo, \& Newman, 2017). Motivation of an individual (intrinsic motivation) and can arise from outside the individual (extrinsic motivation) (Pham, Tučková, \& Chiappetta Jabbour, 2019). And both have an influence on behavior and work performance. Thus, it can be seen that motivation has an effect on employee performance (Khalili, 2017).

Employee work performance means the achievement or contribution given by an employee in carrying out his duties and responsibilities as well as his function as an employee in an educational institution ( $\mathrm{Ygw} \mathrm{He}$, 2017). In addition, work performance is limited as a result of employee work behavior that supports the achievement of output or achievement and is related to efforts to complete their duties within a certain period of time. (Astakhova, 2015). The results reflected in this behavior are influenced, among others, by motivation (Jiang, Zhao, \& Ni, 2017). Indicators that need to be considered in work performance are quality of work, quantity of work, work discipline, initiative, and cooperation (Wahyu Ariani, 2013).

\section{LITERATURE REVIEW}

\section{Organizational Citizenship Behavior (OCB)}

Organizational Citizenship Behavior

(OCB) is part of organizational behavior. The personality basis for OCB reflects the characteristics of employees who are cooperative, helpful, caring and sincere. Meanwhile, the basic attitude indicates that employees who are involved in OCB retaliate against organizational actions (Vigoda-Gadot, Beeri, Birman-Shemesh, \& Somech, 2007).

Organizational Citizenship Behavior (OCB) is extra individual behavior, which is not directly or explicitly recognizable in a formal work system, and which in aggregate can increase the effectiveness of organizational functions. Then for further research to formulate OCB even more, namelycontributes to the maintenance and enhancement of the social and psychological context to task support (Kark \& Waismel-Manor, 2005).

\section{Organizational Citizenship Behavior} (OCB) is a term used to identify employee behavior so that he or she can be called a good member. OCB is a form of benefit, extrarole behavior towards colleagues, especially the form of mutual help. From the definitions of the experts, it can be concluded that OCB is an individual extrarole behavior towards colleagues that can increase the effectiveness of organizational functions. Organizations generally believe that to achieve excellence they must strive for the highest individual performance because basically individual performance affects the performance of the team or work group and ultimately affects the overall performance of the organization (Bienstock, Demoranville, \& Smith, 2003).

This behavior arises because of the feeling of being a member of the organization and feeling satisfied if you can do something more to the organization. The feeling of being a satisfied member when doing something more only occurs 
when employees have a positive perception of the organization. OCB is an act of someone outside of their obligations, not paying attention to their own interests. OCB contributes to the welfare of its community, resource transformation, innovativeness and adaptation as well as overall organizational performance including increasing the effectiveness and efficiency of deploying scarce resources, time and problem solving among work units in a collective and interdependent way (Bogler \& Somech, 2005).

This behavior will not receive direct rewards or sanctions whether it is done or not, but the constructive attitude shown by employees through OCB will provide a positive assessment. Organizations need employees who join in good civic behaviors, such as in constructive statements about their work group and organization, help others on their team, volunteer for additional activities, avoid unnecessary conflicts, show concern for property organization, respects the spirit as well as centered rules and regulations, and is willing to tolerate disturbances and losses related to precarious work (Organ, 2018).

\section{OCB Dimensions}

OCB dimensions according to Bogler \& Somech, (2005) is:

1. Helping behavior, namely the behavior of helping each other and preventing laziness at work.

2. Civic virtue, concerning the support of workers for administrative functions in the organization.

3. Sportsmanship, describes workers who emphasize more on the positive aspects than the negative aspects of the organization. Sportsmanship describes a worker's sportsmanship towards the organization.

In this measurement using a scale Bienstock et al., (2003) where this scale measures the OCB dimensions as follows:

1) Helping behavior include:

a. Behavior helps certain people.

b. Replace co-workers who are absent or taking breaks.

c. Helping others whose work is overloaded.

d. Assisting the new employee orientation process even if not requested. e. Help with other people's work when they are not logged in.

f. Take the time to help others with work problems.

g. Become a volunteer to do something without being asked.

h. Helping others outside the department when they have problems.

i. Help customers and guests if they have problems.

2) Civic virtue include:

a. Willingness to tolerate without complaining.

b. Refrain from complaining and swearing activities.

c. Found no fault in the organization.

d. Not complaining about everything.

e. Do not exaggerate the problem out of proportion.

3) Sportmanship include:

a. Keep up with changes and developments in the organization.

b. Read and follow organizational rules.

c. Make judgments about what is best for the organization.

\section{OCB's Underlying Motives}

As with most other behaviors, OCB is determined by many things, meaning that there is no single cause for OCB. Something that makes sense if we apply OCB rationally. According to McClelland, humans have three levels of motives (Vigoda-Gadot et al., 2007), that is:

1. Achievement motive, encourages people to show privileges

(excellence), seek achievement from a task, opportunity or competition.

2. Affilitation motive, encourages people to create, maintain, and improve relationships with other people.

3. The power motive encourages people to seek status and situations where they can control the work or actions of others.

\section{OCB Benefits For The Company}

According to Philip M.Podsakoff, Scott B.MacKenzie, Julie Beth Paine (2000), OCB has 
benefits for the company, OCB benefits for the company include: colleagues.

1. OCB increases the productivity of

2. OCB increases manager productivity.

3. OCB saves resources owned by management and the organization overall.

4. OCB helps save energy resources to maintain function group.

5. OCB is an effective means of coordinating activities team work.

6. OCB enhances the organization's ability to attract and retain the best employees.

7. OCB improves organizational performance stability.

8. OCB enhances the organization's ability to adapt to environmental change.

\section{Work Motivation}

Motivation is a psychological condition resulting from the interaction of employee needs and external factors that affect the behavior of an employee (Danim, 2004). Motivation is a mental state and human mental attitude that provides energy, encourages activities and directs behavior towards achieving satisfying needs (Steel, Svartdal, Thundiyil, \& Brothen, 2018). From the above definition, motivation can be defined as a very important problem in every effort of a group of people working together to achieve organizational goals, the problem of motivation can be considered simple because basically humans are easily motivated, by giving what they want (Graham, 2020).

According to Anderman (2020), Every theory of motivation seeks to describe what humans and humans can become. For this reason, it can be said that a theory of motivation has content in the form of a particular view of humans (Guo, Han, Zhang, Dang, \& Chen, 2015). The theory of motivation is classified into two aspects, namely the theory of satisfaction and the theory of process motivation.

Motivation theory is a theory of this process as opposed to Maslow's theory of needs. Process theories focus on how motivation occurs (Oakley, Himmelweit,
Leinster, \& Casado, 2020). In other words, process theory basically tries to answer the question of how to strengthen, direct, maintain, and stop individual behavior so that each individual works actively according to the manager's wishes (Tsai et al., 2016).

\section{Type Of Motivation}

Motivation is a living phenomenon that has many shades and varieties. In general, motivation can be classified into four types which give color to human activity. Keshavarz \& Karami (2016), states that the motivation given is classified into four parts:

1. Positive Motivation

Positive motivation is the process of giving motivation or an effort to generate motives, where it is directed at trying to influence others so that they work well and enthusiastically by providing certain benefits to them.

2. Negative Motivation

Negative motivation is often said to be motivation that comes from fear. Excessive negative motivation will make the organization unable to achieve its goals.

3. Motivation From Within

Motivation from within arises in the worker when he performs tasks or work and comes from within the worker himself.

4. Motivation from outside

Motivation from outside is motivation that arises as a result of the influence that is outside the work and from outside the worker himself.

\section{Factors Affecting Motivation}

Motivation arises due to two factors, namely factors from within humans and factors from outside humans. Factors in humans (called internal motivation) in the form of attitudes, education, personality, experience, knowledge, and ideals. Meanwhile, external factors (external motivation) are in the form of superior leadership style, someone's encouragement or guidance, and situation development (Baumeister, 2016). 
The Importance Of Work Motivation

According to Reeve, (2016) argued that the importance of employee motivation is as follows:

a. Respect, which is giving respect and appreciation fairly. But fair does not mean equal. As in terms of work performance, superiors may not reward everyone. Providing awards based on achievement, rank, experience, and so on.

b. Information, namely by providing information to employees about organizational activities, especially about what to do and how to do it.

c. Behavior.

Seek to change behavior in accordance with the expectations of subordinates. Thus he is able to make employees behave or act in accordance with what is expected by the organization

d. Punishment.

Give punishment to employees who are guilty in a separate room, do not punish in front of other employees because it can cause frustration and degrading.

e. Feeling.

Without knowing how employees' expectations are and what feelings are inside them, it is very difficult for leaders to motivate subordinates. These feelings include a sense of belonging, a sense of participation, a sense of friendship, a sense of belonging to a group, and a sense of achievement.

\section{Work Motivation Indicators}

According to Madden, Rashid, \& Zainol (2016), explained that employee work motivation is influenced by physical needs, the need for security and safety, social needs, the need for self-esteem, and the need for self-actualization. Then the need factor is reduced to an indicator to determine work motivation, namely:

1. Physiological, indicated by the provision of decent wages to employees, giving bonuses, food allowances, transportation fees, housing facilities, and so on.

2. Security, indicated by work security and safety facilities, which include workers' social security, pension funds, health benefits, health insurance and work safety equipment.

3. Social, indicated by interacting with other people, including by establishing a harmonious working relationship, 5 he need to be accepted in groups and the need to love and be loved.

4. Awards, indicated by recognition and appreciation based on ability, namely the need to be respected and appreciated by other employees and leaders for their work performance

5. Self-actualization, indicated by the nature of the work that is interesting and challenging, where the employee will mobilize his skills, abilities, skills, and potential. In fulfilling this need, companies can carry out education and training.

\section{Work Performance}

Job performance is the result of a person's efforts which are determined by the ability of his personal characteristics and perceptions of his role in the job (Arcelli, Cortellessa, Filieri, \& Leva, 2015). According to (Aryee, Walumbwa, Seidu, \& Otaye, 2016) Work performance is the quality and quantity of work achieved by an employee in carrying out his her duties in accordance with the responsibilities assigned to him.

\section{Factors Affecting Job Performance}

1. Individual Factors

a) Effort (effort) that shows a number of physical and mental synergies used in carrying out task movements.

b) Abilities, namely personal characteristics needed to carry out a task.

c) Role task perception, namely all behaviors and activities that individuals feel necessary to complete a job.

2. Environmental factor

a) Physical condition

b) Equipment

c) Time

d) Material

e) Education

f) Supervision

g) Organizational Design 

h) Training
i) Luck

\section{Job Performance Indicators}

High-paying jobs must be achieved by employees. (Campbell \& Lambright, 2014) states that measures that need to be considered in work performance include:

1. Work quality.

The assessment criteria are work accuracy, work skills, work accuracy, and work tidiness.

2. Working quantity.

The assessment criterion is speed of work.

3. Work discipline.

The assessment criteria are following supervisor's instructions, complying with company regulations, and complying with time attendance.

4. Initiative.

The assessment criteria are always active or enthusiastic about completing work without waiting for orders from the boss, meaning that they are not passive or work on encouragement from the boss.

5. Cooperation.

The assessment criteria are the ability to socialize and adapt and the ability to provide assistance to other employees within the limits of their authority.

\section{The Effect of Organizational Citizenship Behavior on Work Motivation}

An employee who works in an educational institution is certainly based on the desire to fulfill his needs, both the need for clothing, food and shelter. In addition, they also need to fulfill the need for a sense of security at work, an opinion in recognition of the work done, and be able to actualize themselves in the work environment and organization.

With the Organizational Citizenship Behavior towards the work motivation of these employees, they will work optimally to achieve satisfaction in carrying out their work, and not solely to fulfill their needs. So big is the influence of OCB on work motivation in a job, so that it is one of the factors that must be considered by a company to be able to motivate employees in their work. A job that is not based on work motivation will cause results that are not optimal (Blumberg \& Pringle, 1982).

\section{The Influence of Motivation on Job Performance}

Performance is the result of work in quality and quantity that can be achieved by an employee in carrying out tasks in accordance with the responsibilities assigned to him. According to (Waldman, 1994), employee performance (work performance) is the result of work in quality and quantity achieved by an employee in carrying out his duties in accordance with the responsibilities assigned to him. Therefore, it can be concluded that HR performance is work performance, or output, both the quality and quantity achieved by the unitary HR for the period of time in carrying out their work tasks in accordance with the responsibilities assigned to them. In general, high performance is associated with high motivation. Conversely, low motivation is associated with low performance. A person's performance is sometimes not related to the competence they have, because there are self and work environment factors that affect performance. High performance is a function and interaction between motivation,

\section{Performance $=f$ (Motivation $x$ Ability x opportunity)}

In a company a manager is tasked with improving the performance of his employees in ways that encourage employees to work hard at their jobs. The success or failure of a manager in motivating his employees can be seen by the behavior of his employees at work. A person who is highly motivated will work hard to do the job according to the expected target, someone who is not motivated does not want to do his job according to the expected target even does his job in moderation. To improve employee performance, a manager motivates by providing rewards, 
compensation, allowances and bonuses to employees.

Ability is something that is inherent in a person and is innate and manifested in his actions at work, while motivation is a very important aspect to drive one's creativity and ability to do a job, and is always enthusiastic in carrying out that job. Meanwhile, opportunities are needed to explore the abilities and motivations that are accepted as the manifestation of results that make one's performance look good or not. The realization of maximum performance requires an encouragement to generate the will and enthusiasm for work, namely motivation. Motivation serves to stimulate the ability of employees to create maximum performance results as well (Liu Sifeng, 2010).

\section{The Influence of Organizational Citizenship Behavior and Motivation on Job Performance}

It is often thought that employees who are motivated by the influence of the Organizational Citizenship Behavior will perform their jobs better. In many cases, there is often a positive relationship between Organizational Citizenship Behavior and high work performance, but not always strong enough and meaningful (significant) ". He further argued that a higher Organizational Citizenship Behavior was mainly generated by motivation by producing work performance. Not the other way around. Better work performance results in higher rewards. If the job is felt to be fair and adequate, then employee job satisfaction will increase because they receive an award in an appropriate proportion of their work performance. On the other hand,

Meanwhile, Gibson stated, "There is a reciprocal relationship between performance and work motivation. On the one hand, it is said that work motivation causes an increase in employee performance so that satisfied workers will be more productive. On the other hand, work performance can also occur due to work motivation resulting in work performance so that more productive workers will get satisfaction (Glazier, 2015).

\section{Research Sites}

This research will be conducted at PT JNE Kediri City.

\section{Types Of Research}

This type of research is correlational analytic research. In the (Margahana et al., 2018) Correlation analysis is a statistical method used to measure the magnitude of the linear relationship between two or more variables.

\section{Population And Sample}

The population in this study were all 208 employees of PT JNE Kota Kediri, while the sample in this study was part of the population. The sample size uses a minimum sample of 100 employees.

\section{Types And Sources Of Data}

The type of data used is quantitative data. The data used in this study are primary data and secondary data. Primary data obtained from distributing questionnaires to respondents. Meanwhile, secondary data is used to support primary data, in the form of administrative data obtained from documents of PT JNE Kota Kediri.

\section{Method Of Collecting Data}

In this study the authors chose several techniques in accordance with the research design used, namely:

a. Questionnaire

This questionnaire is intended to obtain written information from respondents regarding research variables. The main purpose of making this questionnaire is to obtain information relevant to the objectives of the survey, to obtain information with the highest possible reliability and validity.

b. Documentation

Documentation study is collecting information by studying written sources to obtain secondary data from each institution that is the object of research that is related to this research (H. He, Li, \& Harris, 2012). 
Operational Definition of a Variable

1. OCB

1. Helping behavior

2. Civic virtue

3. Sportsmanship

2. Work motivation

Work motivation is a motive that encourages employees to do work according to their main duties and job functions which are assessed or measured based on the motivator dimensions and hygiene factors.

Indicators for measuring work motivation according include:

a. Physiological, indicated by the provision of decent wages to employees, giving bonuses, food allowances, transportation fees, housing facilities, and so on.

b. Security, indicated by work security and safety facilities, which include workers' social security, pension funds, health benefits, health insurance and work safety equipment.

c. Social, indicated by interacting with other people, including by establishing a harmonious working relationship, the need to be accepted in groups and the need to love and be loved.

d. Awards, indicated by recognition and appreciation based on ability, namely the need to be respected and appreciated by other employees and leaders for their work performance

e. Self-actualization, indicated by the nature of the work that is interesting and challenging, where the employee will mobilize his skills, abilities, skills, and potential. In fulfilling this need, companies can carry out education and training.

2. Work performance

Job performance is the result of a person's efforts which are determined by the ability of his personal characteristics and perceptions of his role in the job. The indicators for measuring this variable are:
a. Work quality.
b. Working quantity.
c. Work discipline.
d. Initiative.
e. Cooperation.

\section{Variable Measurement}

All variables in this study were measured using the Likert scale, which is a scale related to statements about a person's attitude towards something, for example agree-disagree or likedislike in this study, the Likert scale used is with five scales, namely:

- The choice of answer "Strongly Agree" is given a score of 5

- Choice of answer "Agree given a score of 4

- The choice of answer "Neutral" is given a score of 3

- The choice of answer "Disagree" is given a score of 2

- The choice of answer "Strongly Disagree" is given a score of 1

\section{Instrument Test}

Validity and reliability are needed in research. To have a reliable research instrument, the validity and reliability of the measuring instrument must be tested, so that appropriate and reliable data is allowed.

\section{Validity test}

The research instrument is said to be valid if the instrument is able to measure what is desired and can capture data from the variables written correctly. The level of validity of the instrument indicates the extent to which the collected data does not deviate from the intended image. In this study, the validity test was carried out by using the Pearson model product moment correlation approach, which is to correlate the score of the question items for each variable with the total score. If the correlation coefficient value is less than $\alpha=0.05(5 \%)$, it means that the questionnaire has high validity, that is, the statement items in the questionnaire can measure the measuring function as desired. Reliability test the reliability test is used to test the extent to which the instrument can be given relatively the same results and can be measured again on the same subject. A good measuring instrument does not change its measurement, meaning that even though the tool is used many times it will give almost similar results in this study, the reliability test is carried out using the Cronbach Alpha approach. The criterion is that if the Cronbach Alpha value is $>0.60$, it is said that the questionnaire has high reliability. 
Analysis Method

SEM is a complete modeling basically consisting of a measurement model (Measurement Model) and a Structural Model or Causal Model. Some of the steps taken to form the model are as follows: it is used to determine the effect of the independent variables (X1) and (X2) on the dependent variable (Y).

Through SEM, it can also be seen that the closeness of the relationship (R) between the independent variables and the dependent variable, where the correlation coefficient $(\mathrm{R})$ which is close to 1 shows the level of closeness of the relationship that is getting higher between the two types of variables. SEM can also show the magnitude of the contribution of the independent variables in explaining the changes or fluctuations that occur in the dependent variable, where the coefficient of determination $\left(\mathrm{R}^{2}\right)$ which is close to 1.0 shows the magnitude of the contribution of the independent variables to changes in the dependent variable is close to 100\% (Margahana et al., 2018).

\section{Hypothesis Testing}

To test the first hypothesis in this study, the $\mathrm{F}$ test was used, namely the simultaneous coefficient testing by comparing the probability value with alpha $(\alpha)$ of $5 \%$ or 0.05 . The criteria used are if the probability value (Sig) is smaller than $\alpha(0.05)$, it means that the first hypothesis is accepted, on the contrary, if the probability value (Sig) is greater than $\alpha(0.05)$ it means that the first hypothesis is rejected. .

Next, to test the second hypothesis in this study the $\mathrm{t}$ test was used, namely partial coefficient testing by comparing probability valuewith alpha $(\alpha)$ of $5 \%$ or 0.05 . The criteria used are if the probability value ( $\mathrm{Sig}$ ) is smaller than $\alpha(0.05)$, it means that the second hypothesis is accepted, on the contrary, if the probability value (Sig) is greater than $\alpha(0.05)$ it means that the second hypothesis is rejected. .

Finally, to test the third hypothesis in this study, a comparison of numbers is used standardized coefficients (Beta) between the independent variables, the criteria used is if there is an independent variable that has the highest number of standardized coefficients (Beta) compared to other independent variables, then the independent variable is declared to have the greatest or dominant influence on the dependent variable.

\section{RESULTS AND DISCUSSION Research Object}

The object of this research is all employees of PT JNE Kota Kediri from all study programs, hereinafter referred to as population. Total population in this study were all 208 employees of PT JNE Kota Kediri. The sample in this study was part of the population. The sample size uses a minimum sample of 100 employees.

\section{Descriptive Statistical Analysis}

The number of questionnaires from the data that has been distributed is 130 and the data that has been collected is 100 from the questionnaires that have been distributed. From the data collected, the next step was taken, namely tabulating. The purpose of tabulation is to make data easy to organize, add up, and make it easier to organize data for presentation and analysis. The tabulation results were processed using the SmartPLS program which produced statistical descriptions of the research variables.

\begin{tabular}{|l|r|r|r|r|r|}
\hline & $\begin{array}{l}\text { Original } \\
\text { Sample } \\
(\mathbf{O})\end{array}$ & $\begin{array}{l}\text { Sample } \\
\text { Mean (M) }\end{array}$ & $\begin{array}{l}\text { Standard } \\
\text { Deviation } \\
\text { (STDEV) }\end{array}$ & $\begin{array}{l}\text { T Statistics } \\
(\text { I O / } \\
\text { STDEV |) }\end{array}$ & P Values \\
\hline $\begin{array}{l}\text { Motivation -> } \\
\text { Achievements }\end{array}$ & 0.2967 & 0.2929 & 0.0687 & 4.3213 & 0.0000 \\
\hline OCB -> Motivation & 0.6809 & 0.6907 & 0.0599 & 11.3594 & 0.0000 \\
\hline OCB -> Achievements & 0.6322 & 0.6371 & 0.0609 & 10.3818 & 0.0000 \\
\hline
\end{tabular}

\section{Indirect Effect}

Indirect Effect is used to test whether there is an indirect effect. From the table below, it can be concluded that motivation has an indirect effect on achievement. This conclusion is drawn by considering the $p_{-}$value of 0.0002 where this value is less than 0.05 .

Table 4.4 indirect effects 


\begin{tabular}{|c|c|c|c|c|c|}
\hline & $\begin{array}{l}\text { Original } \\
\text { Sample (0) }\end{array}$ & $\begin{array}{l}\text { Sample } \\
\text { Mean (M) }\end{array}$ & $\begin{array}{l}\text { Standard } \\
\text { Deviation } \\
\text { (STDEV) }\end{array}$ & $\begin{array}{l}\text { T Statistics } \\
\text { (| O / STDEV } \\
\text { |) }\end{array}$ & P Values \\
\hline $\begin{array}{l}\text { Motivation -> } \\
\text { Achievements }\end{array}$ & & & & & \\
\hline OCB -> Motivation & & & & & \\
\hline OCB $->$ Achievements & 0.2020 & 0.2028 & 0.0531 & 3.8039 & 0.0002 \\
\hline
\end{tabular}

\section{R Square}

The criteria for the goodness of the model in the first PLS can be seen from the
R-square value as presented in the table below.

Table 4.5 R-square

\begin{tabular}{|l|r|r|r|l|r|}
\hline & $\begin{array}{l}\text { Original } \\
\text { Sample } \\
(\mathbf{O})\end{array}$ & $\begin{array}{l}\text { Sample } \\
\text { Mean } \\
(\mathbf{M})\end{array}$ & $\begin{array}{l}\text { Standard } \\
\text { Deviation } \\
\text { (STDEV) }\end{array}$ & $\begin{array}{l}\text { T Statistics } \\
(\mid \mathbf{O} / \\
\text { STDEV } \mid)\end{array}$ & P Values \\
\hline Motivation & 0.4582 & 0.4754 & 0.0819 & 5.5929 & 0.0000 \\
\hline Achievement & 0.7378 & 0.7476 & 0.0467 & 15,7983 & 0.0000 \\
\hline
\end{tabular}

Based on the table above, it can be seen that the R-square value for motivation is 0.458 . This value shows that the motivation variable can explain $45.8 \%$ of all data on the satisfaction variable.

While the R-Square value of 0.738 for the achievement variable shows that the achievement variable and the motivation variable are able to explain $73.8 \%$ of all the diversity of data on achievement.

\section{Average Variance Extracted (AVE)}

AVE is a statistical test to test the validity of the indicators that compose each latent variable. The AVE value for motivation is 0.6842 , OCB is 0.5896, and achievement is 0.6854

\begin{tabular}{|l|r|r|r|r|r|}
\hline & $\begin{array}{l}\text { Original } \\
\text { Sample (O) }\end{array}$ & $\begin{array}{l}\text { Sample } \\
\text { Mean (M) }\end{array}$ & $\begin{array}{l}\text { Standard } \\
\text { Deviation } \\
\text { (STDEV) }\end{array}$ & $\begin{array}{l}\text { T Statistics } \\
\left(\mid \begin{array}{l}\text { O / } \\
\text { STDEV |) }\end{array}\right.\end{array}$ & P Values \\
\hline Motivation & 0.6842 & 0.6851 & 0.0426 & 16.0660 & 0.0000 \\
\hline OCB & 0.5896 & 0.5932 & 0.0373 & 15,771 & 0.0000 \\
\hline Achievement & 0.6854 & 0.6880 & 0.0438 & 15.6467 & 0.0000 \\
\hline
\end{tabular}

The minimum value for AVE is 0.5. Based on the above results, it can be concluded that the question indicators in the model are valid because they have an AVE value above 0.5

\section{Composite Reliability}

Composite reliability serves to test the reliability of the questionnaire that has been made. The composite reliability value for each latent variable is for motivation 0.8664 , OCB for 0.8763 , and for achievement of 0.9158 . The results of composite reliability will show a satisfactory value if it is above 0.7 .

\begin{tabular}{|l|r|r|r|r|r|}
\hline & $\begin{array}{l}\text { Original } \\
\text { Sample (O) }\end{array}$ & $\begin{array}{l}\text { Sample } \\
\text { Mean (M) }\end{array}$ & $\begin{array}{l}\text { Standard } \\
\text { Deviation } \\
\text { (STDEV) }\end{array}$ & $\begin{array}{l}\text { T Statistics } \\
(\mid \text { O / } \\
\text { STDEV |) }\end{array}$ & P Values \\
\hline Motivation & 0.8664 & 0.8659 & 0.0235 & 36.9380 & 0.0000 \\
\hline OCB & 0.8763 & 0.8767 & 0.0173 & 50.7562 & 0.0000 \\
\hline Achievement & 0.9158 & 0.9158 & 0.0160 & 57.3145 & 0.0000 \\
\hline
\end{tabular}

\section{Cronbach alpha}

Reliability test can also be seen from the Cronbach alpha value of each latent variable. The table below provides the Cronbach alpha results for each latent variable. 


\begin{tabular}{|l|r|r|r|r|r|}
\hline & $\begin{array}{l}\text { Original } \\
\text { Sample (O) }\end{array}$ & $\begin{array}{l}\text { Sample } \\
\text { Mean (M) }\end{array}$ & $\begin{array}{l}\text { Standard } \\
\text { Deviation } \\
\text { (STDEV) }\end{array}$ & $\begin{array}{l}\text { T Statistics } \\
(\mid \text { O / } \\
\text { STDEV |) }\end{array}$ & P Values \\
\hline Motivation & 0.7681 & 0.7663 & 0.0474 & 16.2216 & 0.0000 \\
\hline OCB & 0.8207 & 0.8204 & 0.0289 & 28.3673 & 0.0000 \\
\hline Achievement & 0.8851 & 0.8848 & 0.0239 & 37.0632 & 0.0000 \\
\hline
\end{tabular}

From the results above, it can be concluded that each variable is reliable because the Cronbach alpha value is greater than 0.6

\section{CONCLUSION}

This research is empirical evidence regarding the effect of motivation and OCB on achievement. This study uses a sample of 100 respondents who are employeesPT JNE Kediri City.

The results showed that:

1. Motivation has an effect on OCB where effective motivation can increase or encourage employee achievement.

2. Motivation affects achievement. Where an employee who is committed to the organization will feel happy to be part of the organization, have trust and good feelings for the organization and have a desire to remain in the organization, and intend to do what is best for the organization so that it will generate more achievement.

3. OCB and motivation affect work performance. Where motivation can increase or encourage an employee to have excellent work performance.

\section{SUGGESTION}

Based on the results of the research that has been done, there are several suggestions that can be considered for further research, namely:

1. Future research is expected to be able to conduct research in all units of PT JNE institutions in Indonesia so that the research results are more comprehensive.

2. Future research is expected to be able to test with a more developed model, so that the results of the study can provide a more complex picture.

\section{REFERENCES}

Afsar, B., \& Badir, YF (2016). Person-organization fit, perceived organizational support, and organizational citizenship behavior: The role of job embeddedness. Journal of Human Resources in Hospitality and Tourism, 15 (3), 252-278.
Anderman, EM (2020). Achievement motivation theory: Balancing precision and utility. Contemporary Educational Psychology, 61 (40), 101864.

Arcelli, D., Cortellessa, V., Filieri, A., \& Leva, A. (2015). Control theory for model-based performance-driven software adaptation. QoSA 2015 - Proceedings of the 11th International ACM SIGSOFT Conference on Quality of Software Architectures, Part of CompArch 2015, 6 (4), 11-20.

Aryee, S., Walumbwa, FO, Seidu, EYM, \& Otaye, LE (2016). Developing and Leveraging Human Capital Resource to Promote Service Quality: Testing a Theory of Performance. Journal of Management, 20 (10), 1-21.

Astakhova, MN (2015). The Curvilinear Relationship between Work Passion and Organizational Citizenship Behavior. Journal of Business Ethics, 130 (2), 361-374.

Basu, E., Pradhan, RK, \& Tewari, HR (2017). Impact of organizational citizenship behavior on job performance in Indian healthcare industries: The mediating role of social capital. International Journal of Productivity and Performance Management, 66 (6), 780-796.

Baumeister, RF (2016). Toward a general theory of motivation: Problems, challenges, opportunities, and the big picture. Motivation and Emotion, 40 (1), 1-10.

Bienstock, CC, Demoranville, CW, \& Smith, RK (2003). Organizational citizenship behavior and service quality. Journal of Services Marketing, 17 (4), 357-378.

Blumberg, M., \& Pringle, CD (1982). The Missing Opportunity in Organizational Research: Some Implications for a Theory of Work Performance. Academy of Management Review, 7 (4), 560569.

Bogler, R., \& Somech, A. (2005). Organizational citizenship behavior in school: How does it relate to participation in decision making? Journal of Educational Administration, 43 (5), 420-438.

Bolino, MC, Hsiung, HH, Harvey, J., \& LePine, JA (2015). "Well, I'm tired of tryin '!" organizational citizenship behavior and citizenship fatigue. Journal of Applied 
Psychology, 100 (1), 56-74.

Brockner, J., Flynn, FJ, Dolan, RJ, Ostfield, A., Pace, D., \& Ziskin, IV (2006). Commentary on "radical HRM innovation and competitive advantage: The Moneyball story." Human Resource Management, 45 (1), 127-145.

Campbell, DA, \& Lambright, KT (2014). Program Performance and Multiple Constituency Theory. Nonprofit and Voluntary Sector Quarterly, 45 (1), 1-22.

Devece, C., Palacios-Marqués, D., \& Pilar Alguacil, M. (2015). Organizational commitment and its effects on organizational citizenship behavior in a high-unemployment environment. Journal of Business Research, 69 (5), 1857-1861.

Dharma, Y. (2018). The Effect of Work Motivation on the Employee Performance with Organization Citizenship Behavior as Intervening Variable at Bank Aceh Syariah. Emerald, 1 (1), 7-12.

Ghanbari, S., \& Eskandari, A. (2013). Organizational Climate, Job Motivation and Organizational Citizenship Behavior. International Journal of Management Perspective, 1 (3), 1-14.

Glazier, PS (2015). Towards a Grand Unified Theory of sports performance. Human Movement Science, 56 (30), 139-156.

Graham, S. (2020). An attributional theory of motivation. Contemporary Educational Psychology, 61 (40), 1-11.

Guo, X., Han, X., Zhang, X., Dang, Y., \& Chen, C. (2015). Investigating $\mathrm{m}$-health acceptance from a protection motivation theory perspective: Gender and age differences. Telemedicine and E-Health, 21 (8), 661-669.

He, H., Li, Y., \& Harris, L. (2012). Social identity perspective on brand loyalty. Journal of Business Research, 65 (5), 648-657.

He, YGW (2017). Corporate Social Responsibility and Employee Organizational Citizenship Behavior: The Pivotal Roles of Ethical Leadership and Organizational Justice. Management Decision, 55 (2), 1-37.

Jiang, W., Zhao, X., \& Ni, J. (2017). The impact of transformational leadership on employee sustainable performance: The mediating role of organizational citizenship behavior. Sustainability (Switzerland), 9 (9), 1-17.

Kark, R., \& Waismel-Manor, R. (2005). Organizational citizenship behavior: What's gender got to do with it? Organization, 12 (6), 889-917.

Keshavarz, M., \& Karami, E. (2016). Farmers' proenvironmental behavior under drought: Application of protection motivation theory. Journal of Arid Environments, 127 (49), 128136.

Khalili, A. (2017). Transformational leadership and organizational citizenship behavior: The moderating role of emotional intelligence. Leadership and Organization Development
Journal, 38 (7), 1004-1015.

Koning, LF, \& Van Kleef, GA (2015). How leaders 'emotional displays shape followers' organizational citizenship behavior. Leadership Quarterly, 26 (4), 489-501.

Lam, CF, Liang, J., Ashford, SJ, \& Lee, C. (2015). Job insecurity and organizational citizenship behavior: Exploring curvilinear and moderated relationships. Journal of Applied Psychology, $100(2), 499-510$

Liu Sifeng, LY (2010). Gray Systems Theory and Applications. Journal of Chemical Information and Modeling, 53 (9), 1-15.

Madden, K., Rashid, B., \& Zainol, NA (2016). Beyond the motivation theory of destination image. Tourism and Hospitality Management, 22 (2), 247-264.

Margahana, H., Haryono, S., \& Muftasa, Z. (2018). The Effects of Job Motivation and Job Satisfaction Toward Organizational Citizenship Behavior (OCB) and Its Impact on Job Performance of Paramedical Community Health Centers in the City of Bandar Lampung. Journal of Resources Development and Management, 46 (August), 1-10.

Matta, FK, Scott, BA, Koopman, J., \& Conlon, D. (2015). Does Seeing "Eye To Eye" Affect Work Engagement and Does Seeing "Eye To Eye" Affect Work Engagement And OCB? A Role Theory Perspective on LMX Agreement Department of Management Eli Broad College of Business Michigan State University Department of Man. Academy of Management Journal, 58 (6), 1686-1708.

Newman, A., Nielsen, I., \& Miao, Q. (2015). The impact of employee perceptions of organizational corporate social responsibility practices on job performance and organizational citizenship behavior: evidence from the Chinese private sector. International Journal of Human Resource Management, 26 (9), 1226-1242.

Ng, TWH, Lam, SSK, \& Feldman, DC (2016). Organizational citizenship behavior and counterproductive work behavior: Do males and females differ? Journal of Vocational Behavior, 93 (9), 11-32.

Oakley, M., Himmelweit, SM, Leinster, P., \& Casado, MR (2020). Protection motivation theory: A proposed theoretical extension and moving beyond rationality-the case of flooding. Water (Switzerland), 12 (7), 1-14.

Organ, DW (2018). Annual Review of Organizational Psychology and Organizational Behavior Organizational Citizenship Behavior: Recent Trends and Developments. Annu. Rev. Organ. Psychol. Organ. Behav, 6 (11), 17-18.

Pham, NT, Tučková, Z., \& Chiappetta Jabbour, CJ (2019). Greening the hospitality industry: How do green human resource management practices influence organizational citizenship behavior in 
hotels? A mixed-methods study. Tourism Management, 72 (August 2018), 386-399.

Philip M. Podsakoff, Scott B. MacKenzie, Julie Beth Paine, and DGB (2000). Organizational Citizenship Behaviors: A Critical Review of the Theoretical and Empirical Literature and Suggestions for Future Research. Journal of Management, 26 (3), 513-563.

Pouramini, Z., \& Fayyazi, M. (2015). The Relationship between Positive Organizational Behavior with Job Satisfaction, Organizational Citizenship Behavior, and Employee Engagement. International Business Research, 8 (9), 57-66.

Reeve, J. (2016). A grand theory of motivation: Why not? Motivation and Emotion, 40 (1), 31-35.

Steel, P., Svartdal, F., Thundiyil, T., \& Brothen, T. (2018). Examining procrastination across multiple goal stages: A longitudinal study of temporal motivation theory. Frontiers in Psychology, 9 (4), 1-16.

Tsai, HYS, Jiang, M., Alhabash, S., Larose, R., Rifon, NJ, \& Cotten, SR (2016). Understanding online safety behaviors: A protection motivation theory perspective. Computers and Security, 59 (19), 1-41.

Vigoda-Gadot, E., Beeri, I., Birman-Shemesh, T., \& Somech, A. (2007). Group-level organizational citizenship behavior in the education system: A scale reconstruction and validation. Educational Administration Quarterly, 43 (4), 462-493.

Wahyu Ariani, D. (2013). The Relationship between Employee Engagement, Organizational Citizenship Behavior, and Counterproductive Work Behavior. International Journal of Business Administration, 4 (2), 46-56.

Waldman, DA (1994). the Contributions of Total Quality Management To a Theory of Work Performance. Academy of Management Review, 19 (3), 510-536.

Zhang, Y., Guo, Y., \& Newman, A. (2017). Identity judgments, work engagement and organizational citizenship behavior: The mediating effects based on group engagement models. Tourism Management, 61 (10), 190197. 